Souza, P.G. O planejamento turistico de base comunitária como instrumento de desenvolvimento em assentamentos da reforma agrária no município de Barreiros (PE). Anais do VIII Congresso Nacional de Ecoturismo e do IV Encontro Interdisciplinar de Ecoturismo em Unidades de Conservação. Revista Brasileira de Ecoturismo, São Paulo, v.4, n.4, 2011, p. 570.

\title{
O PLANEJAMENTO TURISTICO DE BASE COMUNITÁRIA COMO INSTRUMENTO DE DESENVOLVIMENTO EM ASSENTAMENTOS DA REFORMA AGRÁRIA NO MUNICÍPIO DE BARREIROS (PE)
}

\author{
Plínio Guimarães de Sousa* \\ *Instituto Federal de Educação, Ciência e Tecnologia de Pernambuco - Câmpus Barreiros \\ E-mail: plinio@barreiros.ifpe.edu.br
}

A presente pesquisa é um derivado da dissertação "Complexo Turístico Imobiliário The Reef Club em Barreiros/PE: Implantação, Desenvolvimento e Transformações Socioambientais", projeto de pesquisa do Programa de Pós-Graduação em Desenvolvimento e Meio Ambiente - PRODEMA/UFPE, desenvolvido com o objetivo de identificar os possíveis impactos socioambientais provocados pela implantação de um complexo turístico imobiliário, e demonstrar a insustentabilidade socioambiental desse modelo, contribuindo ao final com alternativas que promovessem desenvolvimento com sustentabilidade naquele município. Para que os objetivos fossem atingidos o estudo se desenvolveu de forma exploratória e qualitativa, através de pesquisas bibliográficas e documentais, entrevistas, observação assistemática e registros fotográficos. A abordagem qualitativa e exploratória permitiu ao pesquisador o conhecimento e análise das principais contribuições teóricas existentes sobre o modelo tradicional de desenvolvimento turístico e sobre o turismo de base comunitária, e seus impactos nas comunidades onde são implantados. A observação assistemática, devido ao seu caráter espontâneo e informal, permitiu ao pesquisador a complementação de dados imprescindíveis à pesquisa ao aplicá-la na análise de três destinos turísticos. Em visitas de campo foram coletados dados primários através da aplicação de entrevistas semi estruturadas, registros fotográficos e checagem de dados levantados na pesquisa bibliográfica e documental. A pesquisa direta, através das entrevistas semi estruturadas, foi realizada com uma amostra não-probabilística da população. A complementação dos dados secundários foi obtida através da pesquisa documental, principalmente em arquivos do empreendimento turístico e dos poderes públicos. Os principais resultados obtidos foram a comprovação da hipótese inicial da insustentabilidade socioambiental do modelo representado pelo The Reef Club, e a contribuição com a aprovação, junto ao Programa Institucional para Concessão de Bolsas de Extensão(PIBEX), do IFPE Campus Barreiros, de um projeto de extensão visando a construção, de forma participativa, do planejamento turístico comunitário em um assentamento da reforma agrária no município de Barreiros-PE. O pesquisador pôde constatar que, a partir da análise comparativa de um caso bem sucedido de turismo de base comunitária, em Prainha do Canto Verde, em Beberibe/CE, com o de dois destinos turísticos tradicionais, Maragogi/AL e Mata de São João/BA, aliada às características socioambientais dos assentamentos da reforma agrária existentes em Barreiros/PE, é possível promover desenvolvimento com sustentabilidade nestas comunidades, e de forma indutora para as demais comunidades do município, no entanto, sob uma outra ótica de desenvolvimento, a da inclusão social, sustentação ecológica e participação comunitária. Desta forma, partindo da teoria para a prática, o projeto original de pesquisa se encerra com a apresentação do projeto de extensão, a ser desenvolvido em um dos 14 assentamentos do município, contribuindo, além da implantação do planejamento turístico comunitário, com o empoderamento da comunidade beneficiada, dando inicio a um processo de encadeamento nas demais comunidades assentadas, e, posteriormente, em toda a comunidade barreirense, possibilitando, desta forma, a formação do capital social, em um ciclo virtuoso que, ao contrário do capital econômico, não se acaba, pondo fim aos "nativos mudos", formando-se, então, uma rede de solidariedade e comportamento recíproco, onde os valores sociais e culturais são partilhados, atendendo, portanto, ao objetivo de impactar socialmente dos projetos de extensão.

Palavras-chave: Planejamento turístico; Turismo comunitário; Capital social. 